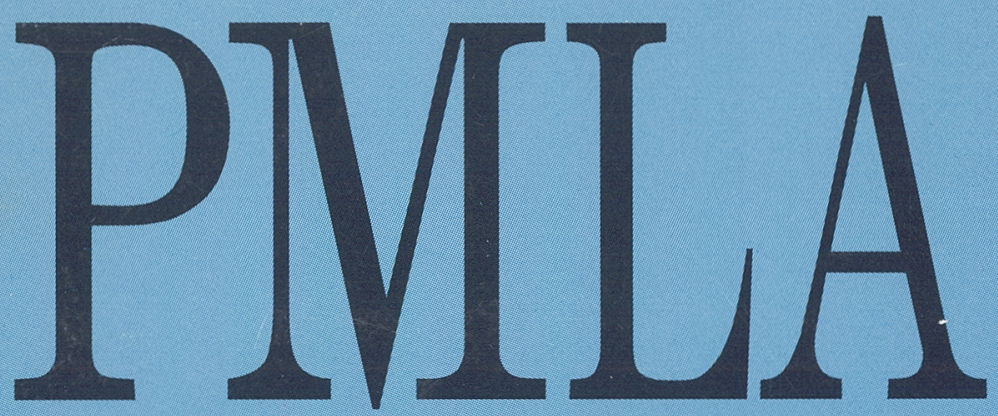

Publications of the

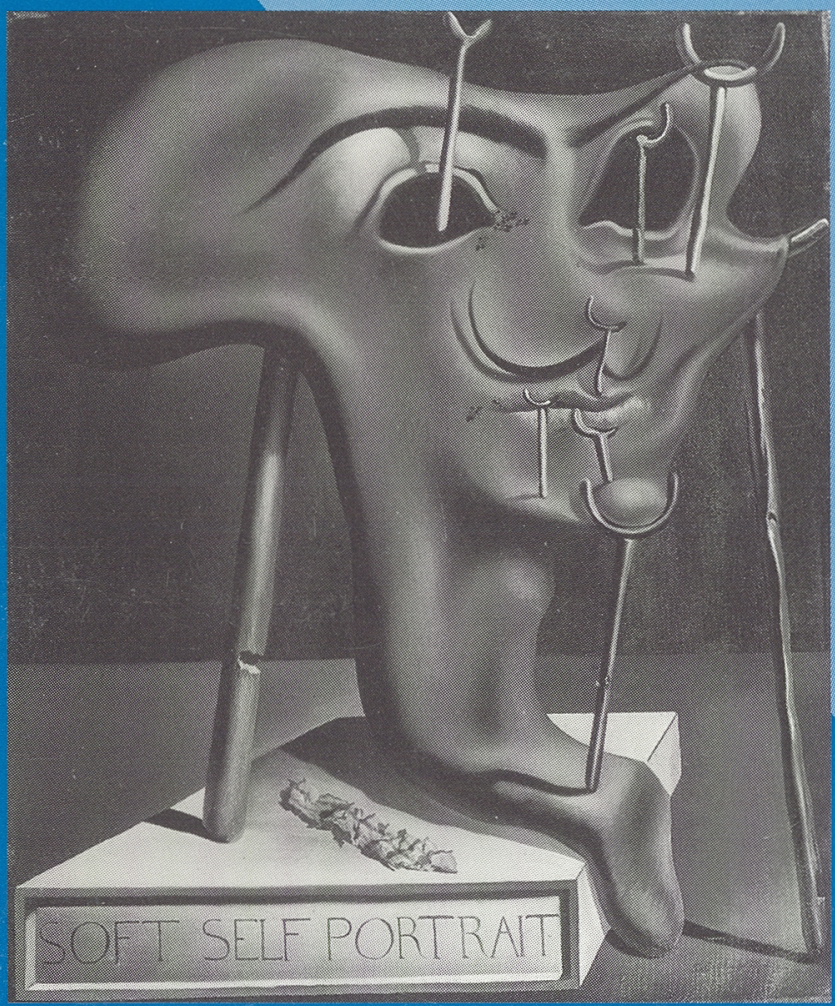

Modern Language

a

Association

in

of America

a

1.996

\title{
OCTOBER
}




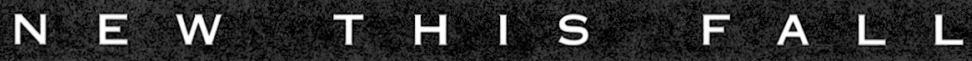

\section{The Future of Academic}

\section{Freedom}

\section{Edited by Louis Menand}

"How we define and protect academic freedom is a matter of great importance not only for universities, but for society as a whole. Louis Menand's book represents a significant and timely contribution. It offers fresh insights and ideas on a subject that is much in need of serious, systematic thinking."-Neil L. Rudenstine, president, Harvard University

cloth \$24.95 256 pages

\section{Curriculum as Conversation}

TRANSFORMING TRADITIONS OF TEACHING AND LEARNING

\section{Arthur N. Applebee}

“Applebee's central point, the need to teach 'knowledge in context,' is absolutely crucial for the hopes of any reformed curriculum. His experience and knowledge give his voice an authority that makes many of the current proposals on both the left and right seem shallow by comparison."-Gerald Graff, University of Chicago

Paper \$12.95 158 pages

Cloth edition available

\section{The Making of the Modern University}

INTELLECTUAL TRANSFORMATION AND THE MARGINALIZATION OF MORALITY

\section{Julie A. Reuben}

"Julie Reuben has written a deeply researched and eloquently argued study of the creation of the research university, showing how its religious foundation was by the 1920 s replaced by ideals of science, secularity, and cosmopolitanism. ... She offers a brilliant analysis of and reflection upon the moral and intellectual implications of this history."-Thomas Bender, New York University

*Paper \$18.95 376 pages
NOW IN PAPER

\section{Shakespeare's Politics}

\section{Allan Bloom}

"A very good book indeed... one which can be recommended to all who are interested in Shakespeare." - G. P. V. Akrigg

Paper \$10.95 160 pages

\section{Patrick White Letters \\ Edited by David Marr}

"White used to ask his friends to burn his letters. ... It's a tribute to David Marr's skills and perseverance that after completing a biography of White,

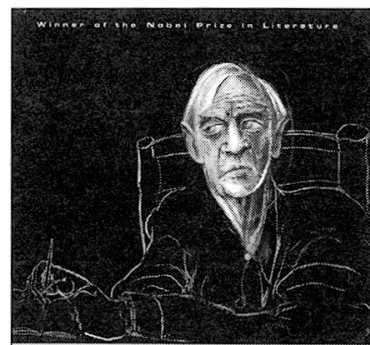

PATRICK WHITE LETTERS he actually obtained White's permission to edit the letters. He has done it well." -Claude Rawson, New York Times Book Review

Paper \$35.00 688 pages 19 line drawings

\section{On the Heights of Despair}

\section{E. M. Cioran}

Translated and with an Introduction by Ilinca Zarifopol-Johnston

"This is self-pity as epigram, the sort of dyspeptic pronouncement that gets most people kicked out of bed but that has kept Mr. Cioran going for the rest of his life." - Judith Shulevitz, New York Times Book Review Paper $\$ 10.95150$ pages

\section{THE UNIVERSITY OF CHICAGOPRESS}




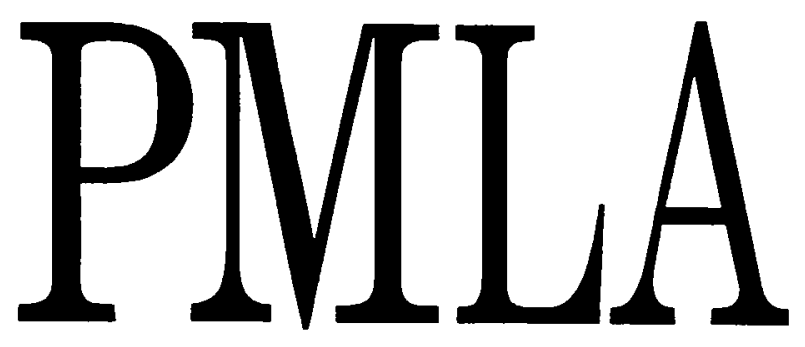

Publications of the

Modern Language Association of America

Volume 111, Number 5

Published six times a year by the association 


\section{The Modern Language Association of America}

Officers for the Year 1996

Executive Council

For the term ending 31 December 1990

For the term ending 31 December 1997

For the term ending 31 December 1998

For the term ending.31 December 1999

Trustees of Invested Funds
President: SANDRA M. GIL BERT, University of California, Daris First Vice President: HERBERT I.JNDIINBERGER, Stanford lniversity Second Vice President: ELAINE SHOWALTER, Princelen University Executive Direclor: PHYLLIS FRANKLIN

LINDA HUTCHEON, liniversity of Torome, Saint George Campus SUSAN KIRKPATRICK, University of California, Sim Diego SUSAN RUBIN SULLIMAN, Harvard University

PETER BROOKS, Yalc Universin ANDREA A LUNSFORD, Ohio Stute Universin, Columbus SYLVIA MOLLOY, New' York Universit? SUSAN NOAKES, University of Minnesonta. Twin Cities:

FRANCES SMITH FOSTER, limmy University PETER UWE HOHENDAHL. Comell University FRANK TROMMLER, University of Pennsylyania

HEATHER DUBROW, University of Wisconsin, Madisom CATHERINE PORTER, Stase Universiry Conllege of New York, Cortlond EVE KOSOFSKY SEDGWICK, Duke University ERIC J. SUNDQUIST, University of California, Los Angeles

CAROLYN G. HEILBRUN. New York, New York HUGH O'NEILL, New York, New York MALCOLM B. SMITH (Managing Trustee), New York, New York

PMLA (ISSN 0030-8129) is published six times a year, in January, March, May, September, October, and November, by the Modern Language Association of America. Membership in the association is open to persons who are professionally interested in the modern languages and literatures. Annual dues, which include subscription to PMLA, are based on members' incomes and are graduated as follows: student members (seven years maximum), $\$ 20$; new regular members (irst year), $\$ 35$; regular members (income under $\$ 15,000$ ), $\$ 25$; regular nembers (income $\$ 1,5,000-\$ 20,000$ ), $\$ 40$; regular members (income $\$ 20,000-\$ 30,000)$ ), $\$ 50$; regular members (income $\$ 30,000-\$ 40,000$ ), $\$ 65$; regular menbers (income $\$ 40,000$ ) $\$ 50,000)$, $\$ 75$; regular members (income $\$ 50,000-\$ 60,000$ ), $\$ 85$; regular members (income $\$ 60,000-\$ 70,000$ ), $\$ 95$; regular members (income $\$ 70,000-\$ 80,000), \$ 105$; regular members (income over $\$ 80,000$ ), $\$ 125$; joint members (two individuals sharing the same household, who receive one subscription to PMLA but two copies of all other publications), add $\$ 20$ to dues calegory of higher-income member; foreign members, same as regular members (use the American-dollar equivalent to ascertain the dues category). Membership applications are available on request.

The subscription price of PMLA for libraries and other institutions is $\$ 108$. A subscription including a bound volume at the end of the year is $\$ 243$, domestic and foreign. Agents deduct $4 \%$ as their fee. Single copies of the January, March, May, and October issues may be obtained for $\$ 12$ each; the September (Directory) issue for $\$ 50$; the November (Program) issue for $\$ 35$.

Issues for the current year are available from the Member and Customer Services Office of the association (212 614-6.38I; membership @mla.org). Claims for undelivered issues will be honored if they are received within six months of the publication date; thereatter the single-issue price will be charged.

For information about the availability of back issues, inquire of Periodical Service Company, Germantown, NY 12526; 914 941-4404. Early and current volumes may be obtained on microfilm from University Microfilms, Ann Arbor, MI 48106. Purchase of current volumes on film is restricted to subscribers of the journal.

The office of publication and editorial offices are located at 10 Astor Place, New York, NY 10003-6981; 212 475-9500; pmlasubmissions@mla.org.

All communications including notices of changes of address should be sent to the Member and Customer Services Office of the association. If a

change of address also involves a change of institutional affiliation, that office should be informed of this fact at the same time.

Periodicals postage paid at New York, NY, and at additional mailing offices.

01996 by The Modern Language Association of America. All rights reserved. Printed in the United States of America.

Library of Congress Catalog Card Number 12-32040. United States Postal Service Number 449-660.

POSTMASTER: Send address changes to PMLA, Member and Customer Services Office, Modern Language Association of America, 10 Astor Place, New York, NY 10003-6981. 


\section{Publications of the Modern Language Association}

Published six times a year Indexes: Vols, 1-50, 1935; 51-60, 1945; 51-79, 1964

Editorial Board

Advisory Committee
Editor: DOMNA C. STANTON, University of Michigan, Ann Arbor Mamaging Ediwr: JUDY GOULDING Assistant Editors: ERIN TROSTLE and ERIC WIRTH Editorial Assistants: JOHN D. GOLBACH and JAMES PONIEWOZIK Advertising Manager and Administrative Assistant: KATHERINE J. FLOREY Submissions Associate: XENI FRAGAKIS

RUSSELL BERMAN, 1997, Stanford University GILES B. GUNN, 1999, University of California, Santa Barbara MICHAEL HOLQUIST, 1997, Yale University' ROBERTA LEE JOHNSON, 1999, University of Kansas CORA KAPLAN, 1997, Rutgers University, New Brunswick CAROL THOMAS NEELY, 1999, University of Illinois, Urbana

LESLIE A. ADELSON, 1998, Ohio State University; Columbus KWAME ANTHONY APPIAH, 1997, Harvard University DANIEL BALDERSTON, 1999, Tulane University TEODOLINDA BAROLINI, 1998, Columbia University CHARLES BERNHEIMER, 1997, University of Pennsylvania CAROL L. BERNSTEIN, 1999, Bryn Mawr College MARC E. BLANCHARD, 1999, University of California, Davis JOSEPH BOONE, 1997, University of Southern California LAURA S. BROWN, 1998, Cornell University ROBERT L. CASERIO, 1998, Temple University ELIN DIAMOND, 1997, Rutgers University, New Brunswick JOANNE F. DIEHL, 1997, University of California, Davis LISA EDE, 1999, Oregon State University, Corvallis STEVEN FINK, 1998, Ohio State University, Columbus RAE BETH GORDON, 1999, University of Connecticut, Storrs SUSAN GUBAR, 1997, Indiana University, Bloomington ALICE C. HARRIS, 1998, Vanderbilt University N. KATHERINE HAYLES, 1998, University of California, Los Angeles JEAN E. HOWARD, 1997, Columbia University KATHRYN HUME, 1997, Penn State University, University Park GEORGE B. HUTCHINSON, 1999, University of Tennessee, Knoxville ULLRICH G. LANGER, 1999, University of Wisconsin, Madison H. MARSHALL LEICESTER, JR., 1997, University of California, Santa Cruz ANGEL G. LOUREIRO, 1999, University of Massachusetts, Amherst JUDITH MAYNE, 1998, Ohio State University, Columbus MICHAEL McKEON, 1997, Rutgers University, New Brunswick ANNE MELLOR, 1997, University of California, Los Angeles TIMOTHY C. MURRAY, 1999, Cornell University ANNE PRESCOTT, 1999, Barnard College JEAN-JACQUES THOMAS, 1999, Duke University WILLIAM MILLS TODD III, 1998, Harvard University KATHLEEN WELCH, 1999, University of Oklahoma JACK ZIPES, 1998, University of Minnesota. Twin Cities 


\section{A Statement of Editorial Policy}

PMLA welcomes essays of interest to those concerned with the study of language and literature. As the publication of a large and heterogeneous association, the journal is receptive to a variety of topics, whether general or specific, and to all scholarly methods and theoretical perspectives. The ideal PMLA essay exemplifies the best of its kind, whatever the kind; addresses a significant problem; draws out clearly the implications of its findings; and engages the attention of its audience through a concise, readable presentation. Manuscripts in languages other than English are accepted for review but must be accompanied by a detailed summary in English (generally of 1,000-1,500 words) and must be translated into English if they are recommended to the Editorial Board. Articles of fewer than 2,500 words or more than $9,(0) 0$ words are not considered for publication. The word count includes notes but excludes works-cited lists and translations, which should accompany foreign language quotations. The MLA urges its contributors to be sensitive to the social implications of language and to seek wording free of discriminatory overtones.

Only members of the association may submit articles to PMLA. Each article submitted is sent to at least one consultant reader and one member of the Advisory Committec. Articles recommended by these readers are then sent to the members of the Editorial Board, who meet periodically with the editor to make final decisions. Until a final decision is reached, the author's name is not made known to consultant readers, to members of the Advisory Committee and the Editorial Board, or to the editor. Because the submission of an article simultaneously to more than one refereed journal can result in duplication of the demanding task of reviewing the manuscript, it is PMLA's policy not to review articles that are under consideration by other journals. An article found to have been submitted elsewhere will not be published in PMLA even if it has already been accepted for publication by the Editorial Board.

Submissions, prepared according to The MLA Style Manual, should be sent in duplicate and addressed to the Managing Editor, PMLA, Modem Language Association, 10 Astor Place, New York, NY 10003-6981. With each submission please include a self-addressed envelope and enough postage for both copies to be returned. Authors' names should not appear on manuscripts; instead, a cover sheet, with the author's name and address and tho title of the article, should accompany each manuscript. Authors should not reler to themselves in the first person in the submitted text or notes if such references would identify them; any necessary references to the author's previous work, for example, should be in the third person.

\section{Criticism in Translation}

MLA members are invited to submit to the PMLA Editorial Board proposals for translations. Articles, as well as chapters or sections of books that can function as independent units, will be considered. The originals may be in any language. Two types of proposals arc welcome: (1) significant scholarship from earlier periods that has not lost its forcefulness and whose retrieval in English in PMLA would be a noteworthy event for a broad body of readers or (2) contemporary work of sufficient weight and potential influence to merit the attention of the field as a whole.

A member who wishes to make a proposal should first ascertain that no previous English translation exists. The proposer should then provide the managing editor with the following materials: (1) a photocopy of the original essay, (2) an extended summary of the entire essay in English, (3) an introductory statement of approximately 1,000 words, prepared in accordance with MLA style, that will be published with the essay if the essay is accepted, (4) information on the copyright status of the original (if the translation is accepted for publication, the proposer will be responsible for obtaining permission to print it). In addition, if the proposer wishes to serve as translator of the essay or to designate a translator (who must also be an MLA member), a 1,000-word sample of the translation should be submitted; otherwise the Editorial Board will select a translator.

The translated essays should normally not exceed PMLA's 9,000-word limit. The Editorial Board will approve or decline the proposals, evaluate the quality of the translations, and cooperate with the proposers and translators. 


\section{Contents}

Cover illustration: Salvador Dalí (1904-89), Autorretrato blando con bacon asado (Soft Self-Portrait with Grilled Bacon). (C Fundació GalaSalvador Dalí (1996, Figueres).
Special Topic . . . . . . . . . . . . . . . . . 1062

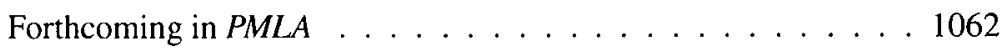

Guest Column. Four Views on the Place of the Personal in Scholarship Michael Bérubé, Cathy N. Davidson, Sylvia Molloy, and David Palumbo-Liu

A Funeral Elegy: W[illiam] S[hakespeare]'s "Best-Speaking Witnesses" (followed by the text of A Funeral Elegy) Donald W. Foster . . . . . . . . . . . . . . . . . . . . . 1080

Shaking Down the Pillars: Lamentation, Purity, and Mallarmé's "Hommage" to Wagner Rebecca Saunders

Beside the Reclining Statue: Ekphrasis, Narrative, and Desire in Middlemarch

Abigail S. Rischin

The Dialectic of Orality and Literacy: The Case of Book 4 of Augustine's De doctrina christiana John D. Schaeffer . . . . . . . . . . . . . . . . . . . . . 1133

Forum

Twenty-six letters on the personal in scholarship . . . . . . . . 1146

Forthcoming Meetings and Conferences of General Interest $\ldots 1170$

Index of Advertisers $\ldots \ldots \ldots \ldots 1171$

Professional Notes and Comment . . . . . . . . . . . 1192 Announcements 1192

Journal Notes 1202

Internet News 1208

Meeting of the MLA Executive Council 1208

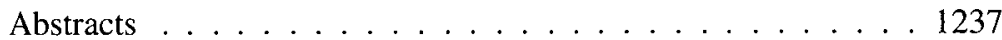

Contents of Volume $111(1996) \ldots \ldots 1239$ 